University of Nebraska - Lincoln

DigitalCommons@University of Nebraska - Lincoln

$1-2008$

\title{
The Overmyer Mastodon (Mammut americanum) from Fulton County, Indiana
}

Neal Woodman

USGS Patuxent Wildlife Research Center, woodmann@si.edu

Jon W. Branstrator

Earlham College, jonb@earlham.edu

Follow this and additional works at: https://digitalcommons.unl.edu/usgsstaffpub

Woodman, Neal and Branstrator, Jon W., "The Overmyer Mastodon (Mammut americanum) from Fulton County, Indiana" (2008). USGS Staff -- Published Research. 581.

https://digitalcommons.unl.edu/usgsstaffpub/581

This Article is brought to you for free and open access by the US Geological Survey at DigitalCommons@University of Nebraska - Lincoln. It has been accepted for inclusion in USGS Staff -- Published Research by an authorized administrator of DigitalCommons@University of Nebraska - Lincoln. 


\title{
The Overmyer Mastodon (Mammut americanum) from Fulton County, Indiana
}

\author{
NEAL WOODMAN ${ }^{1}$ \\ USGS Patuxent Wildlife Research Center, National Museum of Natural History MRC-111, Smithsonian Institution, \\ Washington, DC 20013
}

AND

\author{
JON W. BRANSTRATOR ${ }^{2}$ \\ Geosciences Department, Earlham College, Richmond, Indiana 47374
}

\begin{abstract}
In June 1978 the partial skeleton of an American mastodon, Mammut americanum, was salvaged from a drainage ditch in Fulton County, north-central Indiana. The remains were recovered mostly from ca. $170-260 \mathrm{~cm}$ below the current land surface in marl overlain by peat and peaty marl. The stratigraphy of the site indicates that the remains were deposited in a small, open-water pond that subsequently filled. The skeleton, which is $41-48 \%$ complete, is that of a mature female, ca. 30-34 y old at death based on dental eruption and wear. Postcranial bone measurements indicate that this individual was relatively large for a female. Radiocarbon dating of wood from under the pelvis of the mastodon provided a maximum date of $12,575 \pm 260{ }^{14} \mathrm{C}$ y $\mathrm{BP}[15,550-13,850 \mathrm{cal}$ y $\mathrm{BP}]$ for the animal, which is up to $2575{ }^{14} \mathrm{C}$ y before the species is believed to have become extinct. Pollen samples from the site corroborate the interpretation that the regional climate was cooler and more humid than at present and supported a mixed spruce-deciduous parkland assemblage. The relatively small size of the molars of this and other mastodons from Indiana supports the hypothesis that late-glacial mastodons-just prior to their extinction-were smaller in size relative to earlier, full-glacial conspecifics. The relationship between molar size and body size is not clear, however, and there may be geographical factors as well as a temporal influence to size variation in these animals.
\end{abstract}

\section{INTRODUCTION}

During the excavation of an agricultural drainage ditch in 1976 on the farm of Robert Overmyer northwest of Rochester, Indiana, skeletal remains of a proboscidean were encountered by Mr. Van Horn, the operator of the dredger. Jon Branstrator, James B. Cope and James Wells, representing Earlham College's Joseph Moore Museum, Richmond, Indiana, obtained permission to salvage the remains from the site (Fig. 1, \#24). During 1227 June 1978, we were members of a team of students, faculty, and alumni from Earlham College that recovered and preserved the skull and partial skeleton of a late Pleistocene American mastodon, Mammut americanum. The remains of the "Overmyer Mastodon", subsequently were transferred to the Cincinnati Museum of Natural History (now the Cincinnati Museum Center) in exchange for a series of casts of other large Pleistocene mammals. The Overmyer Mastodon (CMC VP-1) is permanently deposited at that institution.

Despite having been excavated more than a quarter century ago, no formal report on the Overmyer Mastodon was ever produced. Relevant details of the excavation site, such as the stratigraphic and sedimentological contexts of the remains and the radiometric date

\footnotetext{
${ }^{1}$ e-mail: woodmann@si.edu

2 e-mail: jonb@earlham.edu
} 


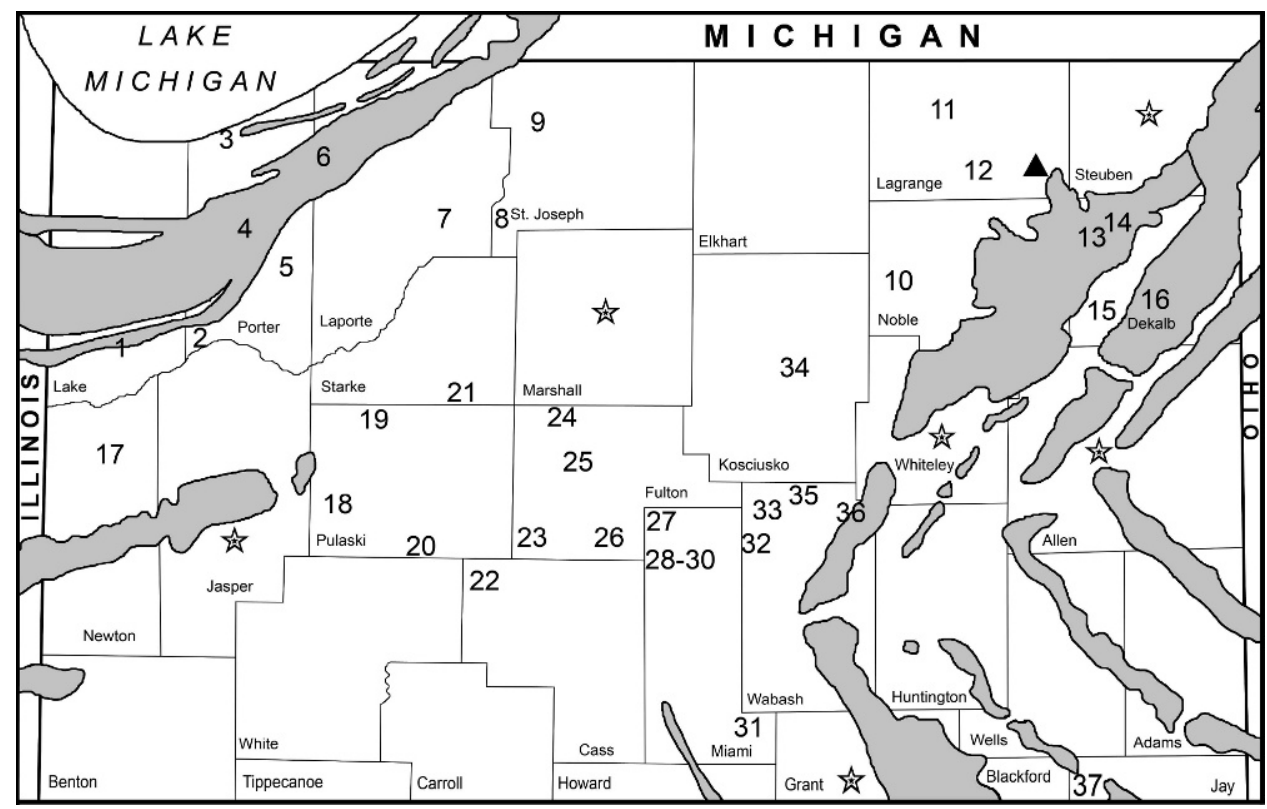

FIG. 1.-Map of northern Indiana illustrating Wisconsin moraines and moraine complexes (gray) and occurrences of American mastodon remains (numerals). Solid triangle is the location of the Pretty Lake pollen site. Stars represent counties with vague records of mastodons or with records beyond the border of the map (see Collett, 1883; Phinney, 1884; Dryer, 1889; Hay, 1923; Lyon, 1936; Richards, 1984). Key to numbered localities: (1) Lake Co. (Hay, 1923); (2) ca. 3 mi sE Hebron, Porter Co. (Blatchley, 1898; Hay, 1923); (3) sand pit north of Dune Park, Porter Co. (USNM uncataloged molar); (4) 2 mi SW Valparaiso, Porter Co. (Blatchley, 1898; Hay, 1923); (5) ca. 5 mi se Valparaiso, Porter Co. (Hay, 1923); (6) Delco Mastodon, Laporte Co. (Turnbull, 1958); (7) Duncker Mastodon, Laporte Co. (Lyon, 1931); (8) Place Mastodon, $1.5 \mathrm{mi}$ WNW Walkerton, St. Joseph Co. (Richards, 1984); (9) ca. 12 mi W Notre Dame, St. Joseph Co. (Hay, 1923); (10) Richmond Mastodon, ca. 2.5 mi se Cromwell, Noble Co. (Sanford, 1935); (11) ca. 4 mi NW LaGrange, Lagrange Co. (Hay, 1923); (12) near Oliver Lake, Johnson Township, Lagrange Co. (Wayne, 1960); (13) ca. 5 mi W Waterloo, Dekalb Co. (Holland, 1905; Hay, 1923); (14) 3 mastodons, ca. 5 mi NE Waterloo, Dekalb Co. (Holland, 1899; Hay, 1923); (15) Garrett Mastodon, 2 mi S Garrett, Dekalb Co. (Simpson, 1934); (16) Waterloo Mastodon, Dekalb Co. (Faunmap, 2006); (17) Beaver Lake, Newton Co. (Hay, 1923); (18) Huppert Farm Mastodon, Pulaski Co. (Faunmap, 2006); (19) ca. $2 \mathrm{mi}$ W Denham [“about $15 \mathrm{mi}$ northwest of Winamac”-Gidley, 1916], Pulaski Co. (Hay, 1923; Lyon, 1936); (20) 5 mi W Oak, Pulaski Co. (Hay, 1923); (21) Kolarik Mastodon, Starke Co., 11,760 $\pm 280{ }^{14}$ C y BP (Jackson et al., 1986; Richards, 1984); (22) 2 mi W Royal Center, Cass Co. (Hay, 1923); (23) Parrish Mastodon, Fulton Co. (Melhorn, 1960); (24) Overmyer Mastodon, Fulton Co.; (25) Wells Mastodon, Fulton Co., 12,000 $\pm 450{ }^{14} \mathrm{C}$ y BP (Gooding and Ogden, 1965); (26) 2 mi SE Fulton, Fulton Co. (Hay, 1923); (27) Miami Co. (Hay, 1923); (28) Cover Mastodon, ca. 12 mi N Peru, Miami Co. (Kintner, 1930); (29) Glasford Mastodon, Miami Co. (Melhorn, 1960); (30) between Macy and Deedsville, Miami Co. (Hay, 1923); (31) between Somerset and Amboy, Miami Co. (Hay, 1923); (32) Wabash Co. (incorrectly reported as in Miami Co. by Hay, 1923); (33) Laketon Mastodon, 2 mi W Laketon, Wabash Co. (Elrod and Benedict, 1891; Hay, 1923); (34) Winona Lake, Koskiusko Co. (USNM 8881, 8882); (35) Lewis Mastodon, $300 \mathrm{~m} \mathrm{~S}$ Wabash/Kosciusko Co. line, Wabash Co., 11,160 $\pm 90{ }^{14} \mathrm{C} y$ BP (Hunt and Richards, 1992); (36) North Manchester Mastodon, ca. 3 mi E North Manchester, Wabash Co. (Elrod and Benedict, 1891; Hay, 1923); (37) western Penn Township, Jay Co. (McCaslin, 1883; Hay, 1923) 
associated with the mastodon, have not been generally available. Although remains of mastodons are relatively common late Pleistocene fossils in the southern Great Lakes region comprising northern Illinois, Indiana and Ohio (Hay, 1923; Lyon, 1936, 1939; Osborn, 1936), few have been adequately studied. Our recent search of the Faunmap online database (Faunmap Working Group, 1994) yielded a listing of only nine late Quaternary mastodon sites in Indiana. Hence, an account of the stratigraphy, sedimentology and paleontology of the radiocarbon-dated Overmyer Site may significantly enrich the scientific record for northern Indiana, aid in better understanding late Pleistocene environmental change in the southern Great Lakes region, and provide additional evidence of how a nowextinct species responded to environmental change. Herein, we provide a detailed account of the site at which the Overmyer Mastodon was encountered, report on the state of the remains, and review the paleoecological landscape in which the Overmyer Mastodon lived and died.

\section{Materials ANd Methods}

Recovered remains of the Overmyer Mastodon were compared with those reported previously; with the composite Randolph Mastodon in the Joseph Moore Museum, Earlham College; and with additional remains there and at the National Museum of Natural History, Washington. Measurements of bones and teeth were taken with a caliper and are reported in mm, unless otherwise stated. Bone measurements follow Agenbroad (1994) and Lister (1996). Dental terminology follows Saunders (1977). We follow the convention of labeling the sequence of mastodon cheek teeth $\mathrm{dP}^{2} / 2$ through $\mathrm{M}^{3} / 3$ (rather than $\mathrm{M}^{1} /{ }_{1}$ through $\mathrm{M}^{6} /{ }_{6}$ ). Age was determined from dental progression and wear (Savage, 1955; Simpson and Paulo Couto, 1957), following Saunders's (1977) comparisons to modern African elephants (Laws, 1966; Haynes, 1991) with corrections provided by Jachmann (1988). We estimated body size of the Overmyer Mastodon, specifically shoulder height, using greatest length of the humerus, following Harington et al. (1974; see also Osborn, 1942), who showed that greatest length of the humerus averaged 36\% of shoulder height for Mammut americanum. This percentage, however, was based originally on only two mounted specimens, so these estimates should be used with caution.

Sex of the Overmyer Mastodon was determined from size and from characteristics of the skull (Osborn, 1936). Like modern proboscideans, male American mastodons tended to be smaller than females (Haynes, 1991) and have more massive and more strongly curved tusks. The larger tusks required broader alveoli that extend more ventrally than in females. In lateral view of a male skull, a horizontal plane intersecting the ventral margin (maxillary portion) of the tusk alveolus typically is even with, or ventral to, a parallel plane intersecting the occlusal surface of the upper molars. In females and immature males, the ventral margin of the tusk alveolus is dorsal to the molar occlusal surface (Osborn, 1936).

Stratigraphy of the Overmyer Mastodon Site was carefully recorded during the excavation of the site. A series of sediment samples collected from the northeast corner of the excavation pit was processed in 1979 for pollen grains using standard procedures (Faegri and Iverson, 1975), including boiling in $\mathrm{KOH}$, treatment in $10 \% \mathrm{HCl}$ to remove carbonates, HF to remove silicates, standard acetolysis and final washes in glacial acetic acid and tertiary butyl alcohol. Alcoholic safranin was added as a stain and the remaining sediment and pollen grains stored in silicone fluid. Two samples, from $51 \mathrm{~cm}$ (D-10) and $91 \mathrm{~cm}$ (D-18) below the sand layer in the lower marl unit (see Stratigraphy below), ultimately were inspected for preserved pollen grains. Counting was done on a stereo microscope at $400 \times$ with critical identifications done at $1000 \times$. Broken pollen grains of Picea and Pinus that 
included at least one complete bladder were tallied as $1 / 2$ of a grain. In D-10, pollen grains were scarce and in poor condition and only 28 grains were counted. In sample D-18, 97 pollen grains were counted.

Radiometric analysis was carried out by the Center for Applied Isotope Studies, University of Georgia, Athens (UGa). We use the abbreviation " "14 $\mathrm{C}$ y BP" (carbon-14 y before present) to distinguish uncorrected radiocarbon dates and "cal y BP" (calibrated years before present) to denote calibrated dates. ${ }^{14} \mathrm{C}$ dates were calibrated using the OxCal Program version 3.10 (Bronk Ramsey, 1995, 2001) with atmospheric data from the northern hemisphere from Reimer et al. (2004). Resulting dates are presented with a 2 sigma range (95.4\% confidence interval).

Specimens examined for this study are listed in Appendix 1. Abbreviations used for specimen repositories are: American Museum of Natural History, New York (AMNH); Cincinnati Museum Center, Cincinnati (CMC); Joseph Moore Museum, Earlham College, Richmond (EC); National Museum of Natural History, Washington (USNM).

\section{Geographical and Geological Setting}

\section{STUDY SITE}

The Overmyer Mastodon Site (Fig. 1) is located in a drainage ditch bordering an agricultural field about $14 \mathrm{~km}$ northwest of Rochester, in Richland Township, Fulton Co., Indiana (ca. $41^{\circ} 08^{\prime} 54^{\prime \prime} \mathrm{N}, 86^{\circ} 20^{\prime} 55^{\prime \prime} \mathrm{W}$, and $\mathrm{S} 1 / 2, \mathrm{NE} \mathrm{1/4}, \mathrm{NE} \mathrm{1/4}, \mathrm{SW} \mathrm{1/4}$, sec. 7, T31N, R2ERutland, Indiana Quadrangle). Surface elevation at the site is ca. $228 \mathrm{~m}$. The drainage ditch runs nearly west-east $\left(\mathrm{S} 88^{\circ} \mathrm{E}\right)$. Water in this minor ditch flows eastward into the Cowan Ditch, which runs south into Eddy Creek, a tributary of the Tippecanoe River. At the beginning of the excavation, this section of the ditch was ca. $270 \mathrm{~cm}$ deep, and in crosssection, it measured ca. 210-240 cm wide at the base and $1200 \mathrm{~cm}$ wide at the top.

Soil at the Overmyer Site is Gilford fine sandy loam, which is typified as a deep, poorlydrained soil on nearly level surfaces that are frequently ponded. Because of its drainage characteristics, the soil in its natural state is poorly suited to trees (Furr, 1987). Although the contemporary landscape is dominated by farmland, the pre-settlement vegetation in northwestern Fulton County was oak-hickory forest with extensive areas of seasonal and permanent wetlands that included sedge meadows, cattail marshes, ponds, bogs and wooded swamps (Lindsey, 1961; Lindsey et al., 1965). Mean annual temperature during 1951-1974 at Rochester, about 14 km southeast of the Overmyer Mastodon Site, was 9.4 C, and mean annual precipitation was $940.3 \mathrm{~mm}$ (Furr, 1987). Physiographically, Fulton County is in the Northern Moraine and Lake Region of Indiana (Wayne and Zumberge, 1965). It is south of the Valparaiso Moraine, which marks the southern terminus of the Lake Michigan lobe of the Laurentide ice sheet during its $15,500{ }^{14} \mathrm{C}$ y BP [ca. 18,900-18,720 cal y $\mathrm{BP}$ ] advance, and north of the Union City Moraine, which represents the southern terminus of the Lake Erie Lobe at that time (Mickelson et al., 1983).

Within Fulton Co., there are three other published mastodon sites (Fig. 1). The Overmyer Mastodon Site is ca. $10 \mathrm{~km}$ north of the Wells Mastodon Site, Rochester Twp., dated at 12,000 $\pm 450{ }^{14} \mathrm{C}$ y BP [15,250-12,950 cal y BP] (Gooding and Ogden, 1965); ca. $17 \mathrm{~km}$ northeast of the undated Parrish Mastodon Site, Wayne Twp. (Melhorn, 1960); and ca. $15 \mathrm{~km}$ north-northwest of an undated find of "several mastodon bones" about $2 \mathrm{mi}$ south of Fulton, Liberty Twp. (Hay, 1923). Few published mastodon sites in northern Indiana have associated radiocarbon dates. Exceptions include the Kolarik Mastodon Site, Starke County, dated at 11,760 $\pm 280{ }^{14} \mathrm{C}$ y BP $[14,250-13,050 \mathrm{cal}$ y BP] (Jackson and Whitehead, 1986), ca. $20 \mathrm{~km}$ to the west of the Overmyer Site, and the Lewis Mastodon Site, 


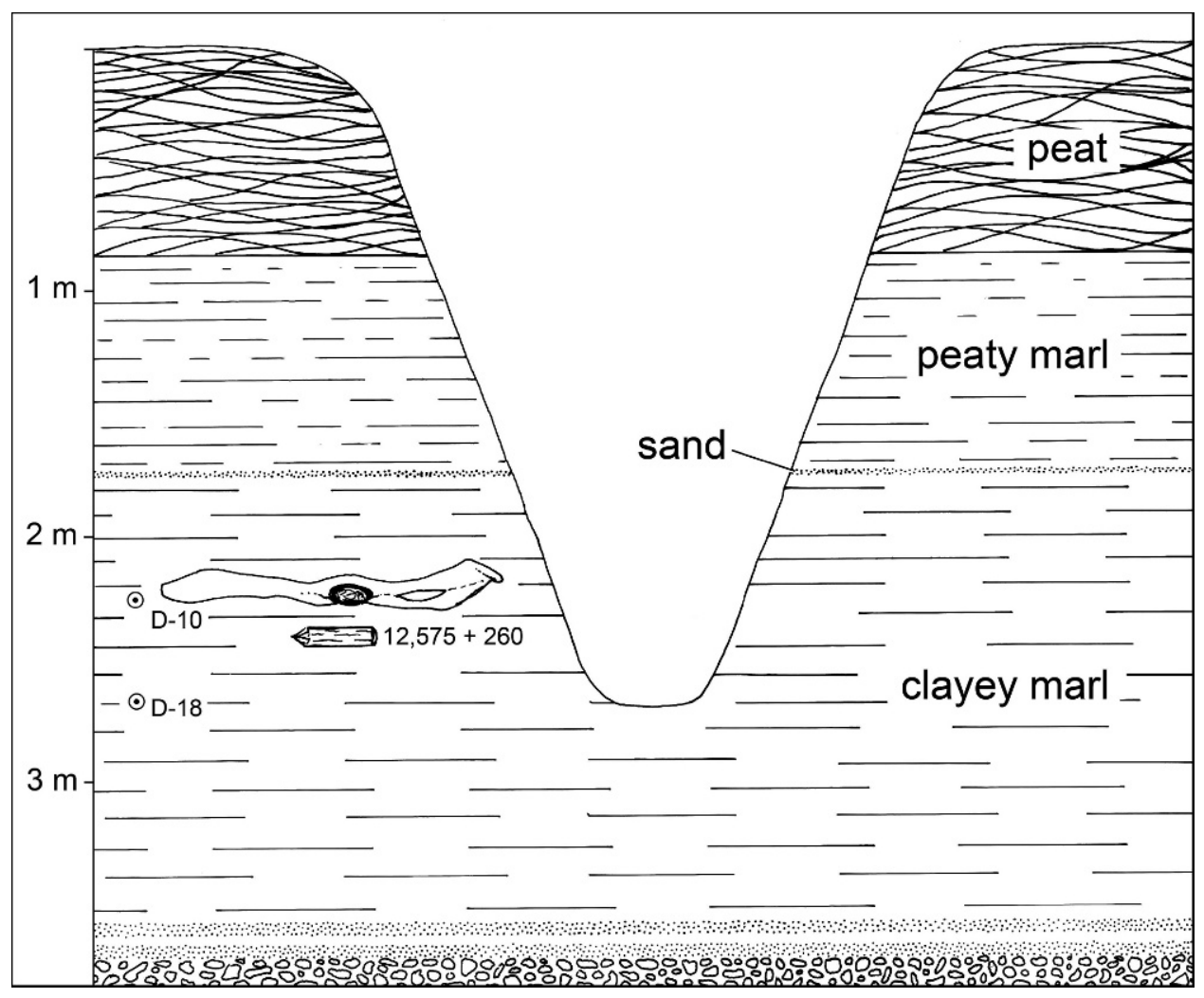

FIG. 2.-Stratigraphic section of the Overmyer Site, illustrating the sequence of sedimentological units (see Stratigraphy) and relative positions of the mastodon's pelvis, wood sample used for ${ }^{14} \mathrm{C}$ dating and pollen samples (D-10, D-18). Vertical exaggeration, $5 \times$

Wabash Co., with a date of $11,160 \pm 90{ }^{14} \mathrm{C}$ y BP [13,220-12,900 cal y BP] (Hunt and Richards, 1992), ca. $48 \mathrm{~km}$ to the east-northeast. Pretty Lake, Lagrange County, whose sediments provided a comprehensive late Quaternary record of vegetational change in the region (Williams, 1974), is ca. $100 \mathrm{~km}$ northeast of the Overmyer Mastodon Site.

\section{STRATIGRAPHY}

A stratigraphic section measured at the north side of the ditch is representative of the sequence of sedimentary units at the site (Figs. 2, 3). Visible at the base, and extending below the contemporary (1978) water table, was a ca. $183 \mathrm{~cm}$-thick, dark, black, organic marl with abundant mollusks. All in situ remains of the mastodon were found in this unit. Probing at the bottom of the drainage ditch revealed that the marl is underlain by two sand layers, each estimated to be ca. $5 \mathrm{~cm}$ thick. These layers were underlain in turn by a gravel layer of unknown thickness that probably marked underlying glacial outwash or till. The upper boundary of the organic marl unit was ca. $172 \mathrm{~cm}$ below the modern land surface. Capping the marl unit was a thin $(0.5-2 \mathrm{~cm})$, distinctive layer of pale, calcareous sand (Fig. 3). Above the sand layer is ca. $85 \mathrm{~cm}$ of blackish, sticky peaty marl containing scattered 


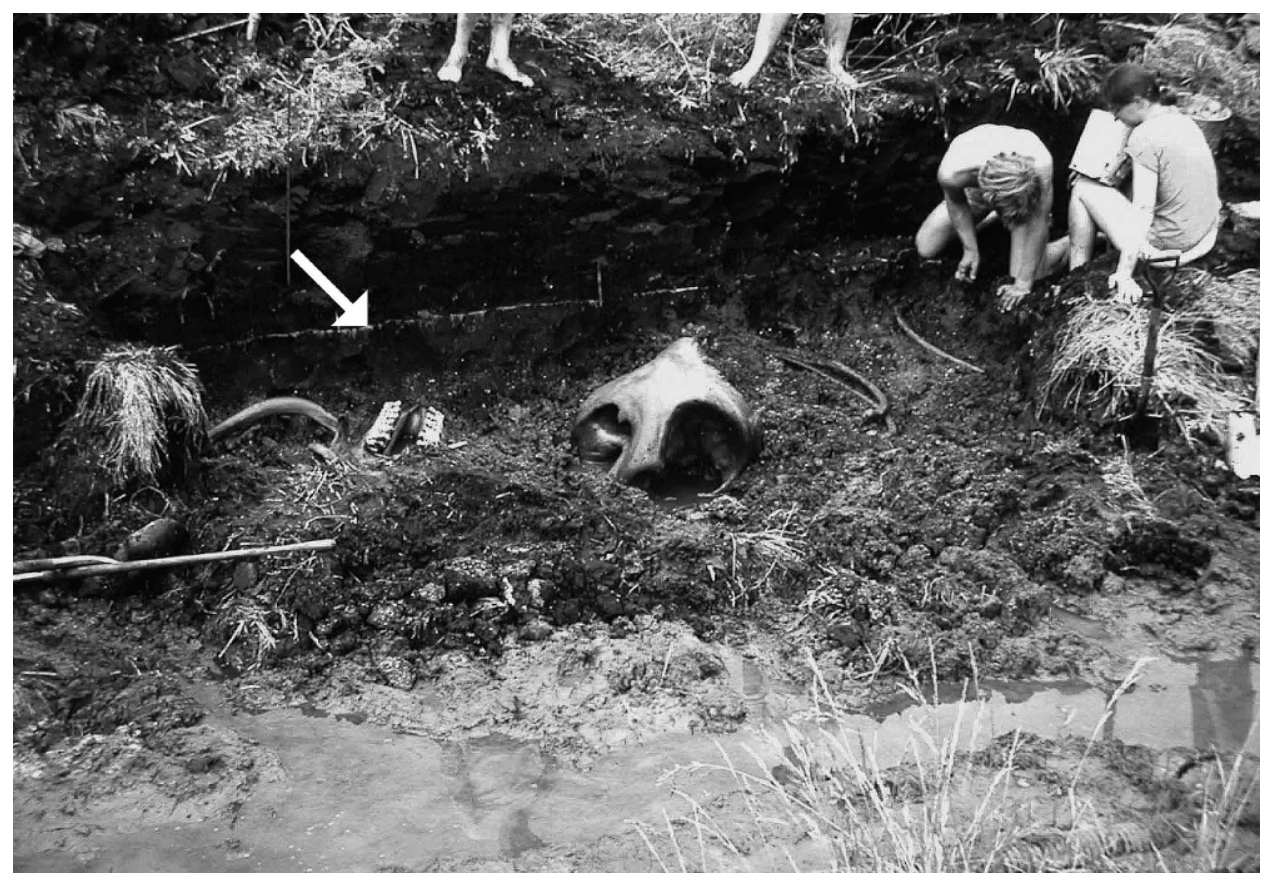

FIG. 3.-North edge of the Overmyer Mastodon excavation site, showing the in situ positions of the cranium, mandible and several ribs. The white arrow points to the distinctive sand layer. Photograph by J. W. Branstratorn

mollusk shells. The peaty marl was overlain by ca. $85 \mathrm{~cm}$ of hard, reddish-brown to blackish, fibrous peat, the uppermost part of which was disturbed by tilling.

The sedimentary record at the Overmyer Mastodon Site is consistent with that of a small, mineral-rich, open-water pond developed on a glacial outwash plain. The uppermost surfaces of a number of vertebrae were measured at $38-46 \mathrm{~cm}$ below the top of the marl. The upper surface of the pelvis also was located within this range of depths, and remains generally tended to be concentrated between ca. 30-60 $\mathrm{cm}$ below the top of the marl. These bones presumably settled in the surface sediments of the pond after the decomposition of much of the animal's soft tissue, and their positions likely mark the approximate level of the sediment-water interface at that time. The distal end of one rib, whose proximal end was $44 \mathrm{~cm}$ below the top of the marl, extended above the marl and ca. $2.5 \mathrm{~cm}$ above the typical level of the sand layer, into the level of the peaty marl. The sand layer draped the protruding portion of the rib without obviously being disturbed by it, and it was apparent that the sand had been deposited around and over the bone. The relationship of this layer to the rib indicates that the mastodon died and was mostly covered by sediment prior to the deposition of the sand. The vertical location of the mastodon's skeleton in the section indicates that the pond was open water at the time these remains were deposited and that the pond remained open for some time thereafter. If the pond followed the typical sequence of Indiana peat wetlands, it eventually succeeded through time to a fen, a peat bog, and a forested peatland (Swinehart and Parker, 2000)

Stratigraphy at the Overmyer Site is comparable to those reported from the nearby Wells and Kolarik mastodon sites (Gooding and Ogden, 1965; Jackson and Whitehead, 1986) and, 
to a lesser extent, from Pretty Lake (Williams, 1974). The thin sand layer at the Overmyer Mastodon Site is distinctive, and its relative position in the section suggests that it may be the stratigraphic equivalent of the ca. $30 \mathrm{~cm}$-thick Unit 2 sand at the Wells Mastodon Site, the 5$7 \mathrm{~cm}$-thick sand layer at the Kolarik Mastodon Site and possibly the $22 \mathrm{~cm}$-thick sand in pollen zone 1c of Core E at Pretty Lake. At the first two sites, like the Overmyer Mastodon Site, the sand unit is underlain by marl and overlain by peat. Pretty Lake is still an openwater lake that is deeper and larger in areal extent than the filled ponds at the other three sites. In that sequence, the sedimentary units are thicker and the sand layer is sandwiched between two clays. These sand layers have been interpreted as representing a period of dune formation in the region that lasted from $12,600-10,900{ }^{14} \mathrm{C}$ y BP at Pretty Lake (Williams, 1974), from 11,760 to $10,830{ }^{14} \mathrm{C}$ y BP at the Kolarik Mastodon Site, and may have lasted as late as $9500{ }^{14} \mathrm{C}$ y BP at the Wells Mastodon Site (Jackson and Whitehead, 1986). Deposition of this layer at the Overmyer Mastodon Site began sometime after $12,575{ }^{14} \mathrm{C}$ y BP.

\section{RADIOMETRIC DATING}

A small section of an 8-cm-diameter branch of an unidentified tree species was recovered ca. $61 \mathrm{~cm}$ below the top of the organic marl, ca. $15 \mathrm{~cm}$ below the acetabulum of the mastodon's pelvis, and ca. $230 \mathrm{~cm}$ below the current ground surface. The sample yielded a date of $12,575 \pm 260{ }^{14} \mathrm{C}$ y BP (UGa-2774) [15,550-13,850 cal y BP]. The wood sample was found below most of the remains of the mastodon and below the depth we estimated for the sediment-water interface at the time the mastodon died (see Stratigraphy). Therefore, we consider the radiocarbon date to represent a maximum age for the mastodon. It is possible that the branch was pushed down into the sediments by the mastodon, in which case the wood and the mastodon should be roughly contemporaneous. The latest reliable date for an American mastodon is $10,395 \pm 100{ }^{14} \mathrm{C}$ y BP $[12,700-11,950 \mathrm{cal}$ y BP] for the Pleasant Lake Mastodon of Michigan (Fisher, 1984), and mastodons are believed to have been extinct by ca. $10,000{ }^{14} \mathrm{C}$ y BP [ca. 11,610-11,330 cal y BP] (Meltzer and Mead, 1983). Hence, the Overmyer Mastodon died up to $2575{ }^{14} \mathrm{C}$ y BP [ca. $2240-4220$ cal y BP] prior to the extinction of its species.

\section{POLLEN ANALYSIS}

Identification of pollen grains from sample D-10, from $51 \mathrm{~cm}$ below the top of the sand layer (Fig. 4), yielded 4 whole and 15 partial grains of Picea (spruce: 42.8\%); 1 Pinus (pine: 3.6); 2 Ostrya/Carpinus (hornbeam/ironwood: 7.1); 3 Quercus (oak: 10.7); 1 Betula (birch: 3.6); 7 Fraxinus niger-type (ash: 25.0); and 2 NAP (non-arboreal pollen-1 Amaranthaceae, 1 Humulus?: 7.1\%). Sample D-18, from $91 \mathrm{~cm}$ below the top of the sand layer, included 64 whole and 47 partial grains of Picea (90.7\%); 3 whole and 1 partial grains of Pinus (4.1), including 1 grain of Pinus banksiana (jack pine); 1 Larix (larch: 1.0); 1 Ostrya/Carpinus (1.0); 2 Quercus (2.1); and 1 NAP (1.0).

These samples are insufficient for reconstructing the regional vegetational environment, particularly without the remainder of the sedimentary sequence having been analyzed. The samples provide support, however, for a general interpretation of the sedimentary environment and they are helpful for biostratigraphic correlation with more complete pollen sequences. Both of our samples correspond well with the upper portion of the spruce-dominated unit 1 at the Wells Mastodon Site (Gooding and Ogden, 1965) and with the spruce-ash-herb assemblage (zone K-1) at the Kolarik Mastodon Site (Jackson and Whitehead, 1986). Sample D-18 matches well with the middle of the Picea-Abies-Larix maximum in pollen zone $1 \mathrm{~b}$ in Core $\mathrm{E}$ from Pretty Lake that was estimated to have lasted from 12,978 to $13,800{ }^{14} \mathrm{C}$ y BP (Williams, 1974). Sample D-10 has pollen percentages 


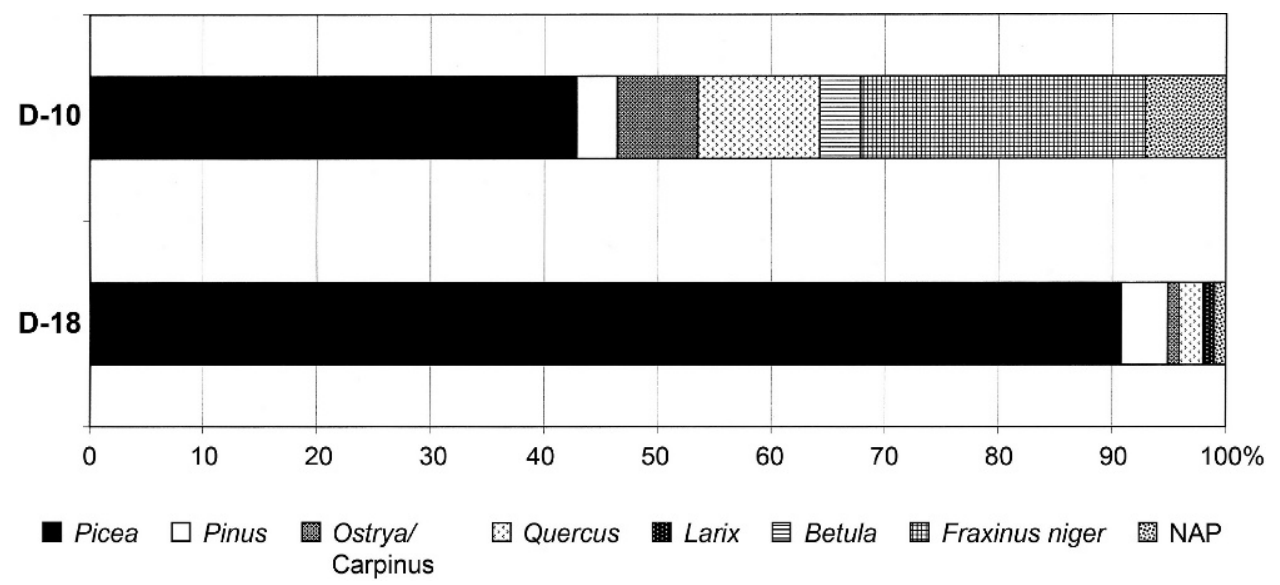

Fig. 4.-Relative percentages of pollen taxa identified in two samples from the Overmyer Mastodon Site. Sample D-18 ( $\mathrm{n}=97$ grains) was from $91 \mathrm{~cm}$ below the top of the sand layer; D-10 $(\mathrm{n}=28$ grains) was from $51 \mathrm{~cm}$

similar to those of the Picea-Fraxinus-NAP maximum in pollen zone 1c at Pretty Lake that is dated at $10,652-12,978{ }^{14} \mathrm{C}$ y BP. Together, these support an interpretation of an open body of water located in an open, spruce-dominated woodland that probably included tamarack, fir, aspen, black ash, oak, and hazel (Gooding and Ogden, 1965; Jackson and Whitehead, 1986). This reconstructed habitat is consistent with boreal environments associated with other mastodons in the Great Lakes Region (Saunders, 1996).

\section{Description of Skeletal Remains}

\section{THE OVERMYER MASTODON}

The majority of the recovered skeleton from the Overmyer Mastodon Site was excavated in situ from the marl unit within the banks of the drainage ditch, and these remains generally were in an extremely good state of preservation. Most bones were entire and exhibited clear surface features. Some of the mastodon remains, however, were found on the surface in the surrounding field, where they had been scattered by the machinery digging the drainage ditch. These bones include at least three ribs, two thoracic vertebrae and numerous fragments of bones, one identifiable as part of the right humerus. Others may have remained in the possession of the ditch excavator and are unaccounted for.

Although most remains from the marl were found within a relatively small area, they were generally disordered. The pelvis, for example, was located on the south side of the ditch; ca. $4 \mathrm{~m}$ south of the cranium, yet a sequence of caudal vertebrae was discovered ca. $76 \mathrm{~cm}$ north of the atlas. Only a few sets of associated bones were discovered articulated or in close proximity in situ: the right fibula lay at an angle across the right tibia; 5 right tarsals were found articulated; and a sequence of six caudal vertebrae was in a discrete grouping.

A total of 106 identifiable skeletal remains of the Overmyer Mastodon were recovered, making the skeleton $41-48 \%$ complete (Table 1$)$. Most $(77-87 \%)$ of the axial skeleton was present, but only 14-16\% of the appendicular skeleton, including portions of the right forelimb (scapula, humerus), right hind limb (innominate, femur, patella, tibia, fibula, nine foot bones) and left hind limb (patella, two foot bones). No remains of the left forelimb or either of the fore feet were recovered. 
TABLE 1.-Comparison of numbers of recovered remains of the Overmyer Mastodon with the numbers of expected elements in the skeleton of the American Mastodon based on Warren (1852); Osborn (1936, 1942); Olsen (1972); Haynes (1991) and Shoshani (2003)

\begin{tabular}{lcc}
\hline \hline & American Mastodon & Overmyer Mastodon \\
\hline cranium (with teeth) & 1 & 1 \\
mandible (with teeth) & 1 & 1 \\
hyoids & 3 & 0 \\
cervical vertebrae & 7 & 6 \\
thoracic vertebrae & $18-20$ & 15 \\
lumbar vertebrae & 3 & 3 \\
sacral vertebrae (fused) & $4-6$ & 6 \\
caudal vertebrae & $22-27$ & 13 \\
ribs & $36-40$ & 37 \\
sternum & 4 & 4 \\
scapulae & 2 & 1 \\
humeri & 2 & 1 \\
radii & 2 & 0 \\
ulnae & 2 & 0 \\
carpals & 16 & 0 \\
metacarpals & 10 & 0 \\
anterior phalanges & $18-28$ & 0 \\
anterior sesamoids & 10 & 0 \\
innominates (fused ilium, ischium, pubis) & 2 & 2 \\
femora & 2 & 1 \\
patellas & 2 & 2 \\
tibia & 2 & 1 \\
fibulae & 2 & 1 \\
tarsals & 14 & 7 \\
metatarsals & 10 & 2 \\
posterior phalanges & $18-28$ & 1 \\
posterior sesamoids & 10 & 106 \\
Totals & $223-256$ &
\end{tabular}

The cranium and mandible of the Overmyer Mastodon were complete. Alveoli for the upper tusks are well-formed and unbroken, but the tusks were not recovered. There is no external evidence of mandibular tusks ever having being present. Cheek teeth present include $\mathrm{M}^{2}$ and $\mathrm{M}^{3}$ in the upper jaw and $\mathrm{M}_{2}$ and $\mathrm{M}_{3}$ in the mandible. Wear on the molars is at about stage 2+ to 3 (Simpson and Paulo Couto, 1957) for $\mathrm{M}^{2} /{ }_{2}$ and about stage 2 for $\mathrm{M}^{3} / 3$, indicating a mature (sensu Savage, 1955) individual, approximately equivalent to an African elephant age of 30-34 y (Saunders, 1977). Saunders (1977) noted that the maximum width of mastodon molars typically was across the metaloph(id) for $\mathrm{M}^{3} / 3$ and across either the metaloph(id) or tetraloph(id) for $\mathrm{M}^{2} /{ }_{2}$. In the Overmyer Mastodon, maximum width for all molars was across the metaloph(id), although the measured difference between metaloph(id) and tritoloph(id) on any single tooth was minor (Appendix 3).

Based on the measured length of its humerus (829 mm-Appendix 2), we estimated the shoulder height of the Overmyer Mastodon to be $2302 \mathrm{~mm}(7.5 \mathrm{ft})$. These measurements indicate the individual was close to the average body size for the species, and it was comparable in size to a large female or a small male mastodon (Table 2). The molars, 
TABLE 2.-Comparative shoulder heights $(\mathrm{mm})$ of selected mastodons estimated from lengths of humeri following Harington et al. (1974). Although sample sizes are low, identified males $(\mathrm{n}=4)$ are all larger than identified females $(\mathrm{n}=3)$. Abbreviations: F, female; M, male; ?, sex unknown

\begin{tabular}{|c|c|c|c|c|}
\hline & Sex & $\begin{array}{l}\text { Length of } \\
\text { humerus }\end{array}$ & Length of femur & $\begin{array}{c}\text { Estimated height at } \\
\text { shoulder }\end{array}$ \\
\hline Boney Spring, $\mathrm{MO}^{\mathrm{a}}$ & ? & 1001 & - & 2781 \\
\hline Lewis Mastodon, IN ${ }^{\mathrm{b}}$ & $?$ & $993^{\mathrm{c}}$ & 1108 & $2754^{\mathrm{c}}$ \\
\hline Stroh Mastodon, IN ${ }^{d}$ & $?$ & $989^{\mathrm{c}}$ & 1104 & $2744^{\mathrm{c}}$ \\
\hline Boney Spring, $\mathrm{MO}^{\mathrm{a}}$ & ? & 972 & - & 2700 \\
\hline Denver Mastodon ${ }^{\mathrm{e}}$ & M & - & - & 2700 \\
\hline Parrish Mastodon, IN $^{f}$ & $?$ & $993^{\mathrm{c}}$ & 1073 & $2667^{\mathrm{c}}$ \\
\hline Warren Mastodon, $\mathrm{NY}^{\mathrm{g}, \mathrm{h}}$ & M & 950 & 1060 & 2635 \\
\hline Boney Spring, $\mathrm{MO}^{\mathrm{a}}$ & $?$ & 941 & - & 2614 \\
\hline Boney Spring, $\mathrm{MO}^{\mathrm{a}}$ & $?$ & 925 & - & 2569 \\
\hline Boney Spring, $\mathrm{MO}^{\mathrm{a}}$ & $?$ & 924 & - & 2567 \\
\hline Boney Spring, $\mathrm{MO}^{\mathrm{a}}$ & $?$ & 921 & - & 2558 \\
\hline AMNH $27009, \mathrm{AK}^{\mathrm{h}}$ & $?$ & 905 & - & 2514 \\
\hline Kolarik Mastodon, IN ${ }^{\mathrm{d}}$ & $?$ & 886 & 1079 & 2461 \\
\hline Whitfield Mastodon, NY ${ }^{\mathrm{g}, \mathrm{h}}$ & $\mathrm{M}$ & 870 & - & 2450 \\
\hline Boney Spring, $\mathrm{MO}^{\mathrm{a}}$ & $?$ & 860 & - & 2389 \\
\hline Peale Mastodon, $\mathrm{NY}^{\mathrm{i}}$ & M & 860 & - & 2389 \\
\hline Overmyer Mastodon, IN & $\mathrm{F}$ & 829 & - & 2302 \\
\hline Neath Mastodon ${ }^{\mathrm{e}}$ & $\mathrm{F}$ & - & - & 2300 \\
\hline Boney Spring, $\mathrm{MO}^{\mathrm{a}}$ & $?$ & 805 & - & 2236 \\
\hline Boney Spring, $\mathrm{MO}^{\mathrm{a}}$ & $?$ & 787 & - & 2186 \\
\hline Cambridge Mastodon, $\mathrm{NJ}^{\mathrm{j}}$ & ? & 775 & 914 & 2152 \\
\hline Boney Spring, $\mathrm{MO}^{\mathrm{a}}$ & $?$ & 741 & - & 2058 \\
\hline Boney Spring, $\mathrm{MO}^{\mathrm{a}}$ & $?$ & 725 & - & 2014 \\
\hline Christensen Bog, IN ${ }^{k}$ & $\mathrm{~F}$ & 640 & - & 1778 \\
\hline
\end{tabular}

${ }^{\mathrm{a}}$ Saunders (1977); 13,600-16,200 ${ }^{14} \mathrm{C}$ y BP

${ }^{\mathrm{b}}$ Hunt and Richards (1992); length of femur $=1108 \mathrm{~mm} ; 11,160{ }^{14} \mathrm{C}$ y BP

c estimated from length of femur based on ratios for the Warren mastodon (Osborn, 1936)

d Richards (1984)

e Haynes (1991)

f Melhorn (1960)

g Harington et al. (1974)

h Osborn (1936)

${ }^{\mathrm{i}}$ Haynes (1991)

j Warren (1852)

${ }^{k}$ Graham et al. (1983); 13,220-12,060 ${ }^{14}$ C y BP

however, are small relative to those reported for other middle and late Pleistocene Mammut americanum from Indiana and elsewhere (Tables 3, 4; Appendix 3).

The ventral margin of the tusk alveolus of the Overmyer Mastodon is dorsal to the molar occlusal surface (Fig. 5) and the tusk alveoli are relatively small $(112 \times 100 \mathrm{~mm}$-Appendix 2). In contrast, the tusks of the Warren Mastodon, a mature $\left(\mathrm{M}^{2} / 2\right.$ and $\mathrm{M}^{3} / 3$ in wear) male, measured $191 \times 178 \mathrm{~mm}$ in diameter at the base (Warren, 1852). These characters, considered together with its size and age, indicate that the Overmyer Mastodon is a female.

The 10th right rib of the mastodon is distinctly swollen along the middle of its shaft (Fig. 6), indicating that it had been injured, probably broken, and had mostly healed prior 
TABLE 3.-Comparative dimensions $(\mathrm{mm})$ of $\mathrm{M}^{2} /{ }_{2}$. Statistics presented are mean $\pm \mathrm{SD}$ and range, with sample size in parentheses

\begin{tabular}{|c|c|c|c|c|}
\hline & \multicolumn{2}{|c|}{$\mathrm{M}^{2}$} & \multicolumn{2}{|c|}{$\mathrm{M}_{2}$} \\
\hline & Maximum length & Maximum width & Maximum length & Maximum width \\
\hline Michigan $^{a}$ & $\begin{array}{c}120 \\
108-139 \\
(\mathrm{n}=13)\end{array}$ & $\begin{array}{c}97 \\
87-110 \\
(\mathrm{n}=13)\end{array}$ & $\begin{array}{c}120 \\
111-129 \\
(\mathrm{n}=11)\end{array}$ & $\begin{array}{c}99 \\
85-108 \\
(\mathrm{n}=10)\end{array}$ \\
\hline Indiana ${ }^{b}$ & $\begin{array}{c}117 \pm 9 \\
100-129 \\
(\mathrm{n}=8)\end{array}$ & $\begin{array}{r}92 \pm 4 \\
84-96 \\
(\mathrm{n}=8)\end{array}$ & $\begin{array}{c}114 \pm 8 \\
100-122 \\
(\mathrm{n}=7)\end{array}$ & $\begin{array}{c}89 \pm 7 \\
79-98 \\
(\mathrm{n}=7)\end{array}$ \\
\hline $\begin{array}{l}\text { Boney Spring, MO c } \\
\quad[13,600-16,200 \text { y BP }]\end{array}$ & $\begin{array}{c}123 \pm 7 \\
110-137 \\
(\mathrm{n}=34)\end{array}$ & $\begin{array}{c}93 \pm 6 \\
83-104 \\
(\mathrm{n}=34)\end{array}$ & $\begin{array}{c}120 \pm 8 \\
101-135 \\
(\mathrm{n}=37)\end{array}$ & $\begin{array}{c}89 \pm 4 \\
81-99 \\
(\mathrm{n}=37)\end{array}$ \\
\hline $\begin{array}{l}\text { Trolinger Spring, } \mathrm{MO}^{\mathrm{c}} \\
{[29,000-34,000 \mathrm{y} \mathrm{BP}]}\end{array}$ & $\begin{array}{c}115 \pm 6 \\
106-124 \\
(\mathrm{n}=8)\end{array}$ & $\begin{array}{r}91 \pm 4 \\
84-96 \\
(\mathrm{n}=8)\end{array}$ & $\begin{array}{c}114 \pm 8 \\
101-124 \\
(\mathrm{n}=13)\end{array}$ & $\begin{array}{c}86 \pm 6 \\
79-95 \\
(\mathrm{n}=11)\end{array}$ \\
\hline $\begin{array}{l}\text { Jones Spring, } \mathrm{MO}^{\mathrm{c}} \\
\qquad[>40,000-48,900 \text { y BP }]\end{array}$ & $\begin{array}{l}113 \pm 8 \\
102-132 \\
(\mathrm{n}=28)\end{array}$ & $\begin{array}{l}88 \pm 8 \\
79-105 \\
(\mathrm{n}=28)\end{array}$ & $\begin{array}{l}113 \pm 7 \\
105-127 \\
(\mathrm{n}=16)\end{array}$ & $\begin{array}{c}85 \pm 5 \\
78-94 \\
(\mathrm{n}=16)\end{array}$ \\
\hline
\end{tabular}

${ }^{\text {a }}$ Statistics from Skeels (1962); sD not reported

${ }^{\text {b }}$ Statistics calculated using measurements from Richards (1984); Richards et al. (1987); Hunt and Richards (1992); Graham et al. (1983), the Overmyer Mastodon and USNM specimens. We included only measurements of left molars

${ }^{\mathrm{c}}$ Statistics from King and Saunders (1984);ages in ${ }^{14} \mathrm{C}$ y BP

TABLE 4.-Comparative dimensions $(\mathrm{mm})$ of $\mathrm{M}^{3} / 3$. Statistics presented are mean \pm SD and range with sample size in parentheses

\begin{tabular}{|c|c|c|c|c|}
\hline & \multicolumn{2}{|c|}{$\mathrm{M}^{3}$} & \multicolumn{2}{|c|}{ 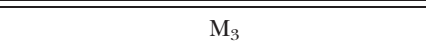 } \\
\hline & Maximum length & Maximum width & Maximum length & Maximum width \\
\hline Michigan $^{a}$ & 192 & 105 & 209 & 105 \\
\hline & $\begin{array}{l}174-223 \\
(\mathrm{n}=10)\end{array}$ & $\begin{array}{l}96-114 \\
(\mathrm{n}=10)\end{array}$ & $\begin{array}{l}184-244 \\
(\mathrm{n}=7)\end{array}$ & $\begin{array}{l}96-118 \\
(\mathrm{n}=6)\end{array}$ \\
\hline Indiana ${ }^{\mathrm{b}}$ & $\begin{array}{c}175 \pm 15 \\
154-203 \\
(\mathrm{n}=14)\end{array}$ & $\begin{array}{c}100 \pm 6 \\
92-110 \\
(\mathrm{n}=14)\end{array}$ & $\begin{array}{c}185 \pm 12 \\
165-199 \\
(\mathrm{n}=9)\end{array}$ & $\begin{array}{c}99 \pm 6 \\
92-109 \\
(\mathrm{n}=9)\end{array}$ \\
\hline Boney Spring, $\mathrm{MO}^{\mathrm{c}}$ & $189 \pm 15$ & $102 \pm 7$ & $192 \pm 15$ & $99 \pm 6$ \\
\hline$[13,600-16,200$ у BP $]$ & $\begin{array}{l}161-219 \\
(\mathrm{n}=32)\end{array}$ & $\begin{array}{l}89-115 \\
(\mathrm{n}=35)\end{array}$ & $\begin{array}{l}170-216 \\
(\mathrm{n}=28)\end{array}$ & $\begin{array}{l}91-111 \\
(\mathrm{n}=33)\end{array}$ \\
\hline $\begin{array}{l}\text { Trolinger Spring, MO }{ }^{\mathrm{c}} \\
{[29,000-34,000 \text { y BP }]}\end{array}$ & $\begin{array}{c}164 \pm 15 \\
151-180 \\
(\mathrm{n}=7)\end{array}$ & $\begin{array}{c}95 \pm 8 \\
83-106 \\
(\mathrm{n}=9)\end{array}$ & $\begin{array}{c}179 \pm 9 \\
162-187 \\
(\mathrm{n}=6)\end{array}$ & $\begin{array}{c}93 \pm 7 \\
80-101 \\
(\mathrm{n}=8)\end{array}$ \\
\hline
\end{tabular}

${ }^{\mathrm{a}}$ Statistics from Skeels (1962); SD not reported

b Statistics calculated using measurements from Richards (1984); Richards et al. (1987); Hunt and Richards (1992); Graham et al. (1983), the Overmyer Mastodon and EC and USNM specimens. We included measurements of left molars, except for specimens for which only right molars were preserved

${ }^{\mathrm{c}}$ Statistics from Saunders (1977); ages in ${ }^{14} \mathrm{C}$ y BP 


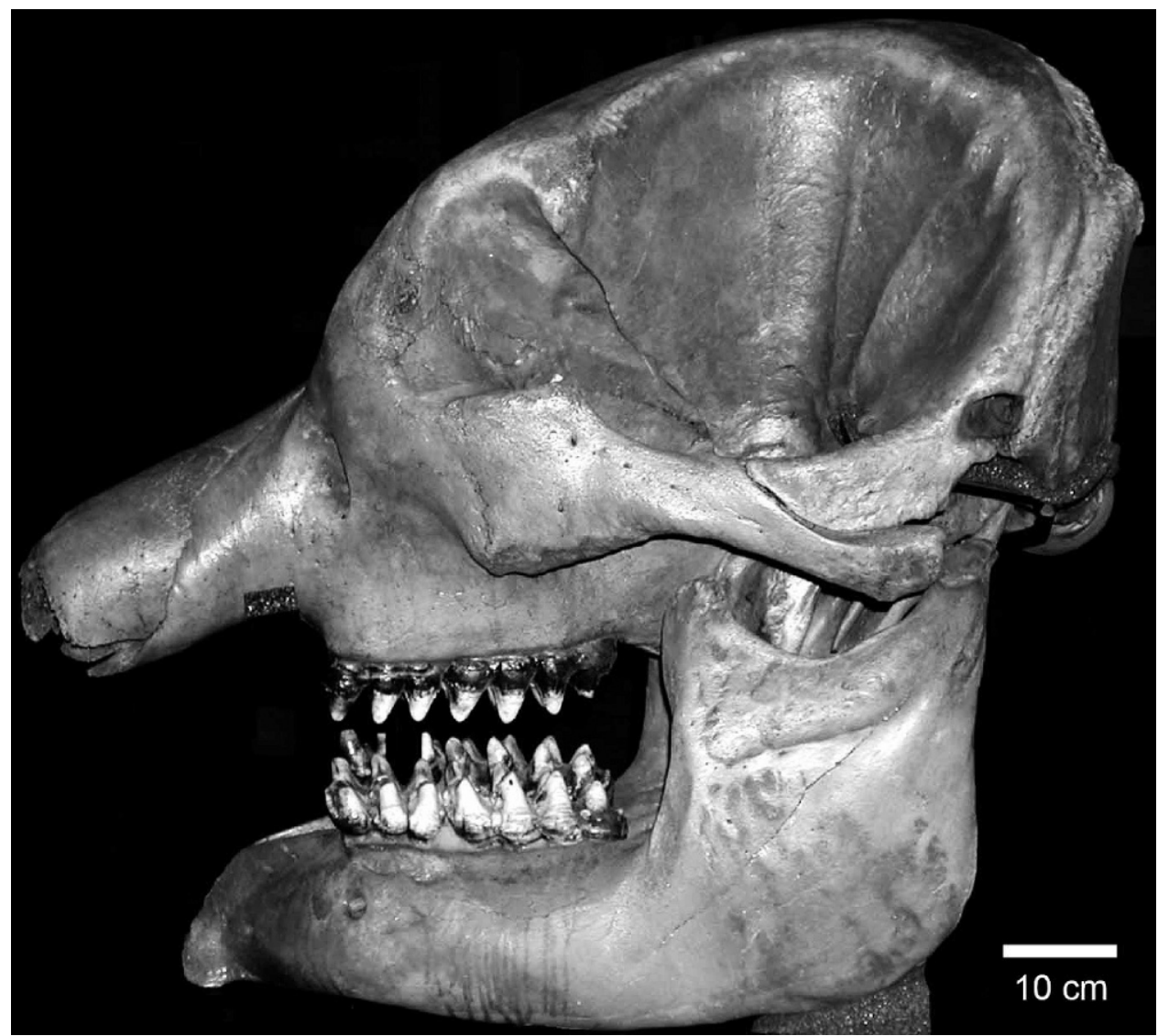

Fig. 5.-Left lateral view of the skull of the Overmyer Mastodon (CMC VP-1). Photograph by J. W. Branstrator

to the animal's death. The two adjacent ribs exhibited no indication of injury. Haynes (1991) stated that female African elephants (Loxodonta africana) break ribs as often as males do, suggesting that broken ribs are not an uncommon phenomenon among modern proboscideans. Healed breaks have been reported from a number of other American mastodons as well. Breaks may be of a single rib, as in the cases of the Overmyer Mastodon and the Richmond Mastodon from Noble County, Indiana (Sanford, 1935), or they may involve two adjacent ribs, as in the Warren Mastodon, Orange Co., New York (Warren, 1852), a mastodon at the University of Wisconsin (Moodie, 1923), and the Cover Mastodon from Miami Co., Indiana (Kintner, 1930). Some skeletons, such as the Warren Mastodon (Warren, 1852) and a specimen in the Peabody Museum from Orange Co., New York (Moodie, 1923), exhibit healed ribs on both sides, indicating multiple injuries and, possibly, multiple episodes of injury.

\section{ASSOCIATED TAXA}

Other skeletal remains recovered in association with the bones of the mastodon included vertebrae and scales of a gar (Lepisosteus sp.), the right sphenotic of a pike, pickerel or 

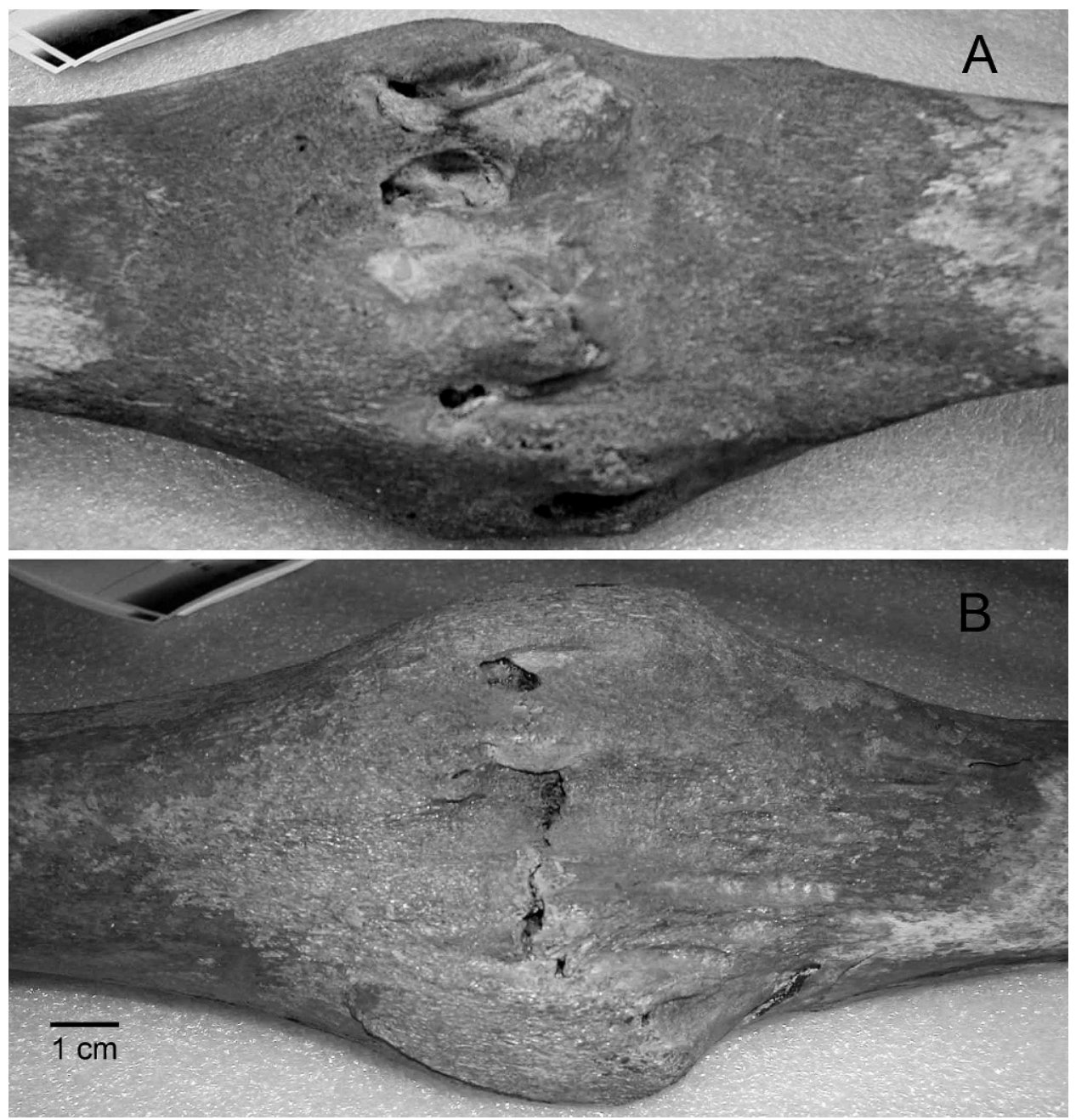

Fig. 6.-Medial (A) and lateral (B) views of the right 10th rib of the Overmyer Mastodon, illustrating a partially healed break. Photograph by J. W. Branstrator

muskellunge (Esox sp.) and two fragmentary thoracic vertebrae of a beaver (Castor canadensis). In addition, the 8-cm-diameter branch submitted for radiocarbon-dating bore incisor marks consistent with those made by a beaver. Beaver-gnawed wood has been reported at a number of other mastodon sites (Marsh, 1867; Meyers, 1868; Osborn, 1899; Hay, 1923; Shoshani et al., 1989; Lepper et al., 1991) and beaver is one of the taxa with which the American Mastodon is commonly associated in late Pleistocene aquatic deposits in the Great Lakes Region (Saunders, 1996). In contrast, identified remains of fish rarely have been reported from mastodon sites. Fossils of Lepisosteus and Esox have been reported previously from the Pleistocene of the upper Great Lakes Region, although records of both are relatively scarce (Bland and Bardack, 1973; Teller and Bardack, 1975; Shoshani and 
Smith, 1996; Seymour, 2004). The presence of all three taxa is consistent our interpretation of an open-water environment at the Overmyer Mastodon Site.

\section{Discussion}

\section{TAPHONOMIC CONSIDERATIONS}

The remains of the Overmyer Mastodon exhibited no evidence of weathering, rodent gnawing or carnivore chewing, nor any other indication that they had been exposed at or above the surface of the pond. Hence, it appears that the recovered skeletal elements were submerged and buried quickly, and they remained buried until excavation of the drainage ditch. The scattered pattern of remains generally was similar to the taphonomic patterns of mastodon skeletons described at Christensen Bog (Graham et al., 1983:18), the Wells Mastodon Site (Gooding and Ogden, 1964), the Orelton Farms Mastodon Site (Thomas, 1952) and other pond and bog sites (e.g., Hartnagel and Bishop, 1922). The distribution of remains at the Overmyer Mastodon Site suggests that much of the skeleton of the mastodon laid on its right side, possibly with the posterior lower than the anterior. Portions of the anterior and left limbs of the skeleton that were not recovered may have separated from the decomposing carcass and may be located in an unexcavated portion of the former pond; they may have been subsequently redistributed by activities of mastodons or other animals; or they may have been removed by scavengers. It is also possible that some parts of the skeleton were in the main area of the drainage ditch and were removed or destroyed by the equipment excavating the ditch.

One cause of death that has been suggested for mastodons discovered in former wetland environments is that they drowned after breaking through a floating vegetation mat of a quaking bog (Holman, 1975, 2001). However, sedimentary and paleontological evidence indicates that the pond at the Overmyer Site was open water at the time the mastodon died. Another common scenario has mastodons becoming mired in the sediments of a small pond or swamp (e.g., Hartt, 1871; Clarke, 1908:45; Hartnagle and Bishop, 1922:1915, 1951, 1969; Goldthwait, 1952; Gooding and Ogden, 1965; Camp, 1981; Graham et al., 1983). Incidents involving modern African elephants becoming stuck in mud or drowning have been observed, although they are uncommon (Haynes, 1991). The wet areas that mastodons frequented may have provided abundant opportunities for becoming bogged down, but it seems most likely that an animal adapted for feeding in wetland environments (e.g., Hallin, 1983; Lepper et al., 1991) generally would be able to avoid such a fate. Based on the depth and distribution of its remains, it seems unlikely that the Overmyer Mastodon was a victim of the muck. Five articulated right tarsals found during the excavation mark the final position of one hind foot in the pond bottom sediments. The dorsal articular surface of the astragalus was at $61 \mathrm{~cm}$ below the top of the sand layer. We estimate the total hind leg length (including fleshy foot pads) of this mastodon to have been ca. $161 \mathrm{~cm}$. Given that the bottom of the foot (including flesh) extended $24 \mathrm{~cm}$ below the top of the astragalus, the bottom of the foot would have been at ca. $85 \mathrm{~cm}$ below the sand layer. Assuming the sediment-water interface was at ca. $38 \mathrm{~cm}$ below the sand at the time the mastodon died (see Stratigraphy), its hind leg would have been mired in ca. $47 \mathrm{~cm}$ of pond mud, or less than half way up its lower leg. It seems plausible that a healthy animal would have to sink much further than mid-shin to become irretrievably stuck. If an animal did become so stuck that it could not extract itself, it may already have been weakened by other factors-starvation, injury, illness. More to the point, if the Overmyer Mastodon had simply become mired, more of the bones from this and the other limbs would have been buried and preserved in closer association with each other. Instead, the foot that was found was incomplete, 
indicating that the foot was not entire when it was finally buried. The generally disordered scattering of remains suggests the bones instead may have gradually come loose and sunk to the bottom of the pond from a floating carcass as it decomposed.

\section{SIZE VARIATION IN MAMMUT AMERICANUM}

King and Saunders (1984) investigated molar sizes (length and width) among series of mastodons from middle Wisconsin (interstadial) deposits at Jones Spring and Trolinger Spring, Missouri, and from the late Wisconsin (full-glacial) sediments at Boney Spring, Missouri, as well as individual mastodons from elsewhere in Tennessee and Missouri. Differences among these teeth are more striking for $\mathrm{M}^{3} / 3$, but data are more complete for $\mathrm{M}^{2} / 2$ (Tables 3,4 ). Variation in tooth size is assumed to be a reliable proxy for fluctuations in body size, and they concluded that size of mid-Wisconsin interstadial mastodons was relatively stable in mid-continental North America. Size subsequently increased during the full-glacial, and it may have decreased again in the late-glacial, just prior to the American mastodon's extinction. Size variations among these temporal populations were interpreted as responses to variations in the quality of the habitat for mastodons. Based on pollen records, smaller mid-Wisconsin mastodons were associated with less favorable pine-parkland environments, whereas the larger full-glacial mastodons inhabited more favorable sprucedominated landscapes. The decreased size of late-glacial mastodons was linked to a deterioration of the environment for mastodons as coniferous forests contracted to isolated islands of habitat within a landscape increasingly dominated by deciduous forests (King and Saunders, 1984).

The small size of the Overmyer Mastodon's molars supports the interpretation of the lateglacial decrease in size (Appendix 3). In fact, the size range of a sample of mastodons from Indiana, most of which presumably are of late-glacial age, also supports this hypothesis (Tables 3, 4). However, a sample of mastodons from Michigan, presumably also late-glacial in age, are larger than late-glacial mastodons from Indiana and Missouri, suggesting that there may be some other factor (e.g., geographic variation) affecting molar size in late Pleistocene mastodons. Although we know that males tended to be larger than females (Table 2), we do not know to what degree, if any, this and other differences in body size are reflected in the size of the molars. To adequately address the hypothesis that late-glacial size variation in mastodon molars reflects environmental quality, it is necessary to more completely address such potentially complicating factors and control for them. Hence, it will require a series of fairly complete mastodon remains from known localities, whose sex can be determined, and for which there are closely associated ${ }^{14} \mathrm{C}$ dates.

\section{LOCAL AND REGIONAL ENVIRONMENTAL INTERPRETATIONS}

Late Wisconsin glacial ice reached its maximum southern limit in the southern Great Lakes region (i.e., Illinois, Indiana, and Ohio) in two advances ca. 21,000 and $20,000{ }^{14} \mathrm{C}$ y BP. The Lake Erie and Lake Michigan lobes of the Laurentide ice sheet repeatedly advanced and retreated over parts of northern Indiana until ca. $14,000{ }^{14} \mathrm{C}$ y BP, after which the southern Great Lakes region remained ice-free (Dreimanis, 1977; Mickelson et al., 1983). The portion of north-central Indiana around the Overmyer Site and between the Union City Moraine of the Lake Erie Lobe and the Valparaiso Moraine of the Lake Michigan Lobe was not overrun by continental glacial ice during the last advance into northern Indiana ca. $15,500{ }^{14} \mathrm{C}$ y BP (Mickelson et al., 1983). However, this interlobal region probably retained buried stagnant ice from the preceding glacial advances at 16,700 and $16,100{ }^{14} \mathrm{C}$ y $\mathrm{BP}$ that extended into Fulton County and remained mostly unforested until after the last regional glacial advance (Wayne, 1968; Dreimanis, 1977; Mickelson et al., 1983). 
From ca. 14,500 to $13,500{ }^{14} \mathrm{C}$ y BP, open tundra-like vegetation dominated, and spruce gradually migrated into the region. Beginning ca. 13,500 and lasting until ca. $13,000{ }^{14} \mathrm{C}$ y $\mathrm{BP}$, spruce parkland with low numbers of fir and larch was the primary vegetational association (Shane, 1987). At about $12,900{ }^{14} \mathrm{C}$ y BP, a glacial readvance reached its maximum extent, forming terminal moraines in the northern Lower Peninsula of Michigan (Mickelson et al., 1983).

After ca. $13,000{ }^{14} \mathrm{C}$ y BP, the climate warmed and a mixed parkland developed as spruce declined in numbers and deciduous trees moved into the region. After ca. $12,600{ }^{14} \mathrm{C}$ y BP, spruce was a minor member of the vegetational community and ash, oaks and ironwood increased in numbers, suggesting that, although warmer, the climate remained cool and moist overall (Williams, 1974; Shane, 1987). We estimate that at ca. $12,575{ }^{14} \mathrm{C}$ y BP, or sometime thereafter, the Overmyer Mastodon died, and its remains were deposited in a small, open-water pond. Vegetation in the immediate area likely was dominated by spruce and ash with oak, ironwood and birch and possibly larch, fir, aspen and hazel. Between 12,000 and 11,000 ${ }^{14} \mathrm{C}$ y BP, the Wells, Kolarik and Lewis mastodons died and were buried in similar small ponds (Gooding and Ogden, 1965; Jackson and Whitehead, 1986). Dune formation may have begun in northeastern Indiana during this period (Williams, 1974), although local sand deposition probably began later (ca. $11,760{ }^{14} \mathrm{C}$ y BP) in the northcentral part of the state (Gooding and Ogden, 1965; Jackson and Whitehead, 1986).

At ca. $10,900{ }^{14} \mathrm{C}$ y BP, spruce had a resurgence and deciduous hardwoods declined as the climate again became cooler and more humid (Williams, 1974; Shane, 1987). This cooling occurred near the end of sand deposition at Pretty Lake, although sand continued to be deposited at the Wells Mastodon Site for some time thereafter. Cooler conditions prevailed until about $10,400{ }^{14} \mathrm{C}$ y BP, when the climate began to warm again, and spruce was replaced by pine- and hemlock-dominated forests. Temperatures continued to increase and by ca. $10,000{ }^{14} \mathrm{C}$ y $\mathrm{BP}$ boreal pine forests were entirely replaced in the southern Great Lakes region by deciduous woodlands (Shane, 1987). By this time, the American mastodon was extinct in North America (Meltzer and Mead, 1983; McAndrews and Jackson, 1988).

\section{SUMMARY}

Shortly after $12,575 \pm 260{ }^{14} \mathrm{C}$ y BP $[15,550-13,850$ cal y BP], a large, mature, female mastodon died in one of a number of small, open-water ponds dotting the landscape in what is now northern Fulton County, Indiana. The cause of this animal's demise is unknown. After death, the body floated on the water's surface and parts of the animal were deposited as the carcass slowly decomposed. At the time, near the end of the late Pleistocene, the continental ice sheet was melting back from its most recent advance, which reached as far as the northern tip of southern Michigan. Northern Indiana, like other parts of the southern Great Lakes region, was cooler and wetter than at present and this climate supported a regional vegetational association of mixed spruce and deciduous parkland. The skeleton of the mastodon remained mostly undisturbed until 1976, when it was struck by machinery excavating a drainage ditch in order to make the former wetland more suitable for agriculture. Much of the skeleton was subsequently salvaged and ultimately deposited in the Cincinnati Museum Center.

Acknowledgments. - The core of the 1978 salvage team included Guy Dauerty, Hanni Dinkeloo, Phil Keyes, Martha Leech, Peter Moulton, Noel Pavlovich and Sarah White. They had occasional assistance from Margaret Branstrator, James Cope, Karen and Robert Haflich, Donna Herring, Earl Holmes, Charles Martin, Jr., Charles Martin, Sr., Charles Oehler, Dan Spence, Jim Wells, Edith, Paul and Thomas Woodman and others. James Wells arranged for access and excavation of the site. Robert, Phyllis and 
Helen Overmyer kindly granted permission to extract the mastodon and associated remains from their farm. Funding was provided by the Joseph Moore Museum and the Cincinnati Museum of Natural History. Glenn Storrs (CMC), John Iverson and Carol Stocksdale (Earlham College) and Jann Thompson and Robert Purdy (USNM Dept. of Paleobiology) kindly permitted access to specimens and records under their care. Randy Culp, Center for Applied Isotope Studies, University of Georgia, provided assistance with understanding the radiocarbon date from the Overmyer Mastodon Site. Alfred L. Gardner, Gary Haynes, Kristopher Helgen, Pamela R. Owen and an anonymous reviewer provided comments on previous drafts of this manuscript.

\section{Literature Cited}

Agenbroad, L. D. 1994. Taxonomy of North American Mammuthus and biometrics of the Hot Springs mammoths, p. 158-207. In: L. D. Agenbroad and J. I. Mead (eds.). The Hot Springs Mammoth Site. A decade of field and laboratory research in paleontology, geology, and paleoecology. The Mammoth Site of South Dakota, Hot Springs.

Bland, J. K. and D. Bardack. 1973. A Pleistocens pike Esox $c f$. lucius from the southern end of Lake Michigan. American Midland Naturalist, 89:138-144.

Bronk Ramsey, C. 1995. Radiocarbon calibration and analysis of stratigraphy: the OxCal Program. Radiocarbon, 37:425-430.

2001. Development of the radiocarbon program OxCal. Radiocarbon, 43:355-363.

Camp, M. J. 1981. Pleistocene history and molluscan paleoecology of the Winameg Mastodon Site, Fulton County, OH. Ohio Journal of Science, 81:230-235.

Clarke, J. M. 1908. Fourth report of the Director of the Science Division. New York State Museum Bulletin, 121:1-203.

Dreimanis, A. 1977. Late Wisconsin glacial retreat in the Great Lakes Region, North America. Annals of the New York Academy of Science, 288:70-89.

Elrod, M. N. And A. C. Benedict. 1891. Geology of Wabash County, p. 192-272. In: S. S. Gorby (ed.). Seventeenth Annual Report of the Indiana Department of Geology and Natural Resources, Indianapolis.

Faegri, K. And J. Iverson. 1975. Textbook of pollen analysis. Hafner Press, New York.

FaunMaP Working Group. 1994. Faunmap: a database documenting late Quaternary distributions of mammal species in the United States. Illinois State Museum Scientific Papers, 25:i-viii, 1-690. (Web site at http://www.museum.state.il.us/research/faunmap/; accessed 23 Jan. 2006).

Fisher, D. C. 1984. Taphonomic analysis of late Pleistocene mastodon occurrences: evidence of butchery by North American Paleo-Indians. Paleobiology, 19:338-357.

FurR, G. F., JR. 1987. Soil survey of Fulton County, Indiana. National Cooperative Soil Survey, U.S. Dept. of Agriculture Soil Conservation Service, US Government Printing Office, Washington, DC.

GidLey, J. W. 1916. The Indiana mastodon. Smithsonian Miscellaneous Collections, 66(3): 28-29.

Goldthwatt, R. P. 1952. Geological situation of the Orleton Farms Mastodon. Ohio Journal of Science, 52:5-9.

Gooding, A. M. And J. G. Ogden, III. 1965. A radiocarbon dated pollen sequence from the Wells Mastodon site near Rochester, Indiana. Ohio Journal of Science, 65:1-11.

Graham, R. W., J. A. Holman and P. W. Parmalee. 1983. Taphonomy and paleoecology of the Christensen Bog mastodon bone bed, Hancock County, Indiana. Illinois State Museum Reports of Investigations, 38:1-29.

HAllin, K. F. 1983. Hair of the American mastodon indicates an adaptation to a semiaquatic habitat. American Naturalist, 23:949 (abstract).

Harington, C. R., H. W. Tipper and R. J. Mott. 1974. Mammoth from Babine Lake British Colombia. Canadian Journal of Earth Sciences, 11:285-303.

Hartnagle, C. A. And S. C. Bishop. 1922. The mastodons, mammoths and other Pleistocene mammals of New York state. New York State Museum Bulletin, 241-242:1-110.

HaRtT, C. F. 1871. Discovery of mastodon remains at Mott's Corners near Ithaca, N.Y. American Naturalist, 5:314-315. 
Hay, O. P. 1923. The Pleistocene of North America and its vertebrated animals from the states east of the Mississippi River and from the Canadian provinces east of longitude $95^{\circ}$. Carnegie Institute of Washington, Washington.

Haynes, G. 1991. Mammoths, mastodons, and elephants. Biology, behavior, and the fossil record. Cambridge University Press, New York.

Holland, W. J. 1899. The mastodon. Popular Science, 33:233-234.

1905. The hyoid bone in Mastodon Americanus. Annals of the Carnegie Museum, 3:464-467.

Holman, J. A. 1975. Michigan's fossil vertebrates. Publication of the Museum, Michigan State University, Educational Bulletin, 2:1-54.

- 2001. In quest of Great Lakes ice age vertebrates. Michigan State University Press, East Lansing.

Hunt, L. L. And R. L. Richards. 1992. The Lewis mastodont (Mammut americanum) locality, Wabash County, north-central Indiana. Proceedings of the Indiana Academy of Science, 101:221-227.

Jachmann, H. 1988. Estimating age in African elephants: a revision of Laws' molar evaluation guide. African Journal of Ecology, 26:51-56.

Jackson, S. T. AND D. R. WhiteheAd. 1986. Late-glacial and early Holocene vegetational history at the Kolarik Mastodon Site, northwestern Indiana. American Midland Naturalist, 115: 361-373.

King, J. E. AND J. J. SAunders. 1984. Environmental insularity and the extinction of the American mastodon, p. 315-339. In: P. S. Martin and R. G. Klein (eds.). Quaternary Extinctions. A prehistoric revolution. The University of Arizona Press, Tucson.

Kintner, E. 1930. Notes on unearthing parts of a mastodon skeleton. Proceedings of the Indiana Academy of Science, 39:237-239.

Laws, R. M. 1966. Age criteria for the African elephant, Loxodonta africana. East African Wildlife Journal, 4:1-37.

Lepper, B. T., T. A. Frolking, D. C. Fisher, G. Goldstein, J. E. Sanger, D. E. Wymer, J. G. Ogden, III and P. E. Hooge. 1991. Intestinal contents of a late Pleistocene mastodont from midcontinental North America. Quaternary Research, 36:120-125.

Lindsey, A. A. 1961. Vegetation of the drainage-aeration classes of northern Indiana soils. Ecology, 42:432-436.

, W. B. Crankshaw and S. A. QAdir. 1965. Soil relations and distribution map of the vegetation of presettlement Indiana. Botanical Gazette, 126:155-163.

Lister, A. M. 1996. Sexual dimorphism in the mammoth pelvis: an aid to gender determination, p. 254-259. In: J. Shoshani and P. Tassy (eds.). The Proboscidea. Evolution and palaeoecology of elephants and their relatives. Oxford University Press, New York.

Lyon, M. W., JR. 1931. A small collection of Pleistocene mammals from Laporte County, Indiana. American Midland Naturalist, 12:406-410.

1936. Mammals of Indiana. American Midland Naturalist, 17:1-373.

1939. Indiana mastodons. Proceedings of the Indiana Academy of Science, 48:246-247.

Marsh, O. C. 1867. Discovery of additional mastodon remains at Cohoes, N.Y. American Journal of Science, 43(127): 115-116.

McAndrews, J. H. And L. J. Jackson. 1988. Age and environment of late Pleistocene mastodont and mammoth in southern Ontario. Bulletin of the Buffalo Society of Natural Sciences, 33:161-172.

Melhorn, W. N. 1960. The Parrish and Glasford mastodons. Proceedings of the Indiana Academy of Science, 69:189-192.

Meltzer, D. J. and J. I. Mead. 1983. The timing of Late Pleistocene mammalian extinctions in North America. Quaternary Research, 19:130-135.

Meyers, D. R. 1868. Proceedings of scientific societies. American Naturalist, 2(1): 56.

Mickelson, D. M., L. Clayton, D. S. Fullerton and H. W. Borns, Jr. 1983. The late Wisconsin glacial record of the Laurentide ice sheet in the United States, p. 3-37. In: H. E. Wright JR. and S. C. Porter (eds.). Late-Quaternary environments of the United States. Vol. 1. The late Pleistocene. University of Minnesota Press, Minneapolis.

Moodie, R. L. 1923. Paleopathology. An introduction to the study of ancient evidences of disease. University of Illinois Press, Urbana. 
Olsen, S. J. 1972. Osteology for the archaeologist. No. 3. The American mastodon and the woolly mammoth. Papers of the Peabody Museum or Archaeology and Ethnology, 56(3): i-viii, 1-47.

Osborn, H. F. 1899. The Newburgh Mastodon. Science, 10:539.

1936. Proboscidea. A monograph of the discovery, evolution, migration, and extinction of the mastodonts and elephants of the world. Vol. 1. American Museum Press, New York.

1942. Proboscidea. A monograph of the discovery, evolution, migration, and extinction of the mastodonts and elephants of the world. Vol. 2. American Museum Press, New York.

Reimer, P. J., M. G. L. Baillie, E. Bard, A. Bayliss, J. W. Beck, C. Bertrand, P. G. Blackwell, C. E. Buck, G. Burr, K. B. Cutler, P. E. Damon, R. L. Edwards, R. G. Fairbanks, M. Friedrich, T. P. Guilderson, K. A. Hughen, B. Kromer, F. G. McCormac, S. Manning, C. Bronk Ramsey, R. W. Reimer, S. Remmele, J. R. Southon, M. Stuiner, S. Talamo, F. W. Taylor, J. van der Plicht and C. E. WEYHENMEYER. 2004. IntCal04 terrestrial radiocarbon age calibration, 0-26 cal kyr BP. Radiocarbon, 46:1029-1058.

Richards, R. L. 1984. The Pleistocene vertebrate collections of the Indiana State Museum with a list of the extinct and extralocal Pleistocene vertebrates of Indiana. Proceedings of the Indiana Academy of Science, 93:483-504.

D. R. Whitehead and D. R. Cochran. 1987. The Dollens Mastodon (Mammut americanum) locality, Madison County, Indiana. Proceedings of the Indiana Academy of Science, 47:571-581.

SAnford, J. T. 1935. The Richmond Mastodon. Proceedings of the Rochester Academy of Science, 7:137-156.

SAunders, J. J. 1977. Late Pleistocene vertebrates of the western Ozark Highland, Missouri. Illinois State Museum Reports of Investigations, 33:1-118.

1996. North American Mammutidae, p. 271-279. In: J. Shoshani and P. Tassy (eds.). The Proboscidea. Evolution and palaeoecology of elephants and their relatives. Oxford University Press, New York.

SAvage, D. E. A survey of various late Cenozoic vertebrate faunas of the Panhandle of Texas, Part II: proboscidea. University of California Publications in the Geological Sciences, 31:51-74.

Seymour, K. L. 2004. Pleistocene vertebrates from the pre-late Wisconsinan Mill Creek site, St. Clair County, Michigan. Michigan Academician, 36:191-212.

Shane, L. C. K. 1987. Late-Glacial vegetational and climatic history of the Allegheny Plateau and the Till Plains of Ohio and Indiana, U.S.A. Boreas, 16:1-20.

Shoshani, J. 2003. Mammut hyoid elements from the Hiscock site; description and implications. Bulletin of the Buffalo Society of Natural Sciences, 37:114-120.

AND G. R. Sмiтh. 1996. Late Pleistocene fishes from the Shelton Mastodon Site (Oakland County, Michigan) and their ecological context. University of Michigan Museum of Paleontology, Contributions, 29:419-433.

—, D. C. Fisher, J. M. Zahiskie, S. J. Thurlow, S. L. Shoshani, W. S. Benninghoff and F. H. Zoch. 1989. The Shelton Mastodon site: multidisciplinary study of a late Pleistocene (Twocreekan) locality in southeastern Michigan. University of Michigan Museum of Paleontology, Contributions, 27:393-436.

Simpson, G. G. and C. Paulo Couto. 1957. The mastodonts of Brazil. Bulletin of the American Museum of Natural History, 112:129-189, 23 plates.

Simpson, P. F. 1934. The Garrett Mastodon. Proceedings of the Indiana Academy of Science, 43:154-155.

Skeels, M. A. 1962. The mastodons and mammoths of Michigan. Papers of the Michigan Academy of Science, Arts, and Letters, 97:101-133.

Swinehart, A. L. and G. R. Parker. 2000. Palaeoecology and development of peatlands in Indiana. American Midland Naturalist, 143:267-297.

Teller, S. And D. Bardack. 1975. New records of late Pleistocene vertebrates from the southern end of Lake Michigan. American Midland Naturalist, 94:179-189.

Thomas, E. S. 1952. The Orleton Farms Mastodon. Ohio Journal of Science, 52:1-5.

Turnbull, W. D. 1958. Notice of a late Wisconsin mastodon. Journal of Geology, 66:96-97.

Warren, J. C. 1852. "Mastodon giganteus" of North America. John Wilson and Sons, Boston.

Wayne, W. J. 1960. The Darrow mastodon. Proceedings of the Indiana Academy of Science, 69:182.

1968. The Erie lobe margin in east-central Indiana during Wisconsin glaciation. Proceedings of the Indiana Academy of Science, 77:279-291. 
And J. H. Zumberge. 1965. Pleistocene geology of Indiana and Michigan, p. 63-84. In: H. E. Wright JR. and D. G. Frey (eds.). The Quaternary of the United States. Princeton University Press, Princeton.

Williams, A. J. 1974. Late-Wisconsin vegetational history of the Pretty Lake region, northeastern Indiana. United States Geological Survey Professional Paper, 686-B.

Submitted 25 OCtober 2006

ACCEPTED 11 July 2007

APPENDIX 1.-Specimens examined

InDIANA: Fulton County: Richland Twp., ca. 14 km northwest of Rochester (CMC VP-1). Gibson County: Greensville (USNM 11792). Koskiusko County: Wayne Twp., [T32N, R6E] Winona Lake (USNM 8881, 8882). Porter County: sand pit north of Dune Park (USNM uncataloged). Pulaski County: W. D. Pattison farm, ca. $15 \mathrm{mi} \mathrm{NW}$ of Winamac and ca. $2 \mathrm{mi} \mathrm{W}$ Denham [section line between SE 1/4, NW 1/4 and NE 1/4, SW 1/4, sec. 9, T31N, R3W] (USNM 8204) (Gidley, 1906; Hay, 1923:96, \#33; Lyon, 1936:336);

Randolph County: near Losantville, J. R. Bookout farm (EC 92-part of Randolph Mastodon).

Oнiо: Preble County: near New Paris, Ross Reed farm (EC 92-part of Randolph Mastodon).

Missouri: Jefferson County: near Kimmswick, Rock Creek (USNM 4984, 4985, 8718). 
APPENDIX 2.-Skeletal measurements (mm) of the Overmyer Mastodon (CMC VP-1)

Numbers in parentheses are comparable to bone measurements by Agenbroad (1994), except for the pelvis, for which they are comparable to those given by Lister (1996).

\section{Cranium}

maximum length of skull (1)

basioccipital length

breadth of nares (3)

breadth across both tusk alveoli (4)

greatest breadth of posterior cranium (6)

posterior nares to premaxilla (8)

anterior nares to premaxilla

minimum width across premaxillae (9)

postorbital breadth (10)

breadth across anterior $\mathrm{M}^{2} \mathrm{~s}$

breadth between anterior $\mathrm{M}^{2} \mathrm{~s}$

breadth across tritolophs of both $\mathrm{M}^{3} \mathrm{~s}$

breadth across occipital condyles (21)

posterior zygomatic breadth (18)

anterior zygomatic breadth

posterior $\mathrm{M}^{3}$ to premaxilla (20)

length of molar left toothrow

length of molar right toothrow

dorsal-ventral internal breadth of left tusk alveolus

dorsal-ventral internal breadth of right tusk alveolus

lateral internal breadth of left tusk alveolus

lateral internal breadth of right tusk alveolus

internal depth of left tusk alveolus

internal depth of right tusk alveolus

\section{Mandible}

breadth across articular condyles (1)

breadth between articular condyles (2)

breadth across anterior $\mathrm{M}_{2} \mathrm{~s}$

breadth between anterior $\mathrm{M}_{2} \mathrm{~s}(9)$

breadth across tritolophids of $\mathrm{M}_{3} \mathrm{~s}$

breadth between tritolophids of $\mathrm{M}_{3} \mathrm{~s}$

maximum length of mandible $(15+16+17)$

length of symphysis (14)

breadth of mandible posterior to right $\mathrm{M}_{3}$

anterior symphysis to posterior of left articular condyle

length of left articular facet (3)

length of right articular facet (3)

breadth of left ascending process (22)

breadth of right ascending process (22)

length of left molar toothrow

length of right molar toothrow

Right humerus

length, greater tubercle to capitulum (1) 
APPENDIx 2.-Continued

Numbers in parentheses are comparable to bone measurements by Agenbroad (1994), except for the pelvis, for which they are comparable to those given by Lister (1996).

Pelvis

height of pelvic aperture (2) 440

minimum width of ilium (5) 189

$\begin{array}{lr}\text { maximum anterior-posterior breadth of acetabulum } & 157\end{array}$

maximum dorsal-ventral breadth of acetabulum 163

ApPEndix 3.-Dental measurements (mm) of the Overmyer Mastodon (CMC VP-1)

\begin{tabular}{|c|c|c|c|c|}
\hline \multirow[b]{2}{*}{ Dentition } & \multicolumn{2}{|c|}{ Upper } & \multicolumn{2}{|c|}{ Lower } \\
\hline & Left & Right & Left & Right \\
\hline \multicolumn{5}{|l|}{$\mathrm{M}^{2} / 2$} \\
\hline maximum length & 100 & 102 & 100 & 102 \\
\hline maximum width at protoloph(id) & 81 & 82 & 74 & 73 \\
\hline maximum width at metaloph(id) & 84 & 84 & 79 & 82 \\
\hline maximum width at tritoloph(id) & 81 & 82 & 79 & 80 \\
\hline \multicolumn{5}{|l|}{$\mathrm{M}^{3} / 3:$} \\
\hline maximum length & 155 & 153 & 165 & 164 \\
\hline maximum width at protoloph(id) & 93 & 93 & 86 & 85 \\
\hline maximum width at metaloph(id) & 96 & 94 & 99 & 99 \\
\hline maximum width at tritoloph(id) & 95 & 92 & 98 & 99 \\
\hline maximum width at tetartoloph(id) & 72 & 70 & 82 & 81 \\
\hline
\end{tabular}

